Volume 2 No. 1, Juni 2017

P ISSN 2442-594X | E ISSN 2579-5708

http://journal.iainlangsa.ac.id/index.php/tibyan

\title{
REFLEKSI ABDULLAH SAEED TENTANG PENDEKATAN KONTEKSTUAL TERHADAP AYAT-AYAT ETHICO-LEGAL DALAM ALQURAN
}

\author{
Reflection Of Abdullah Saeed About Contextual Approaches To Ethico-Legal \\ Verses In The Qur'an
}

\section{Lenni Lestari}

IAIN Zawiyah Cot Kala Langsa, Aceh

lenny_jeumpa@yahoo.com

\begin{abstract}
Awareness of the relationship between text, context and interpreters always experiences dynamics from time to time. From the classical to contemporary times, every interpreter always tries to present the results of interpretations that give benefit to anyone. The same is true for contextual interpreters, such as Fazlur Rahman, Amina Wadud, Muhammad Syahrur, and Khaled Abou El Fadl who will be briefly reviewed in this article. This article is the result of Abdullah Saeed's reflection on four contemporary commentators in interpreting the verses of legal ethics. Abdullah Saeed is an Australian scientist from the Maldives. Abdullah Saeed is also present to give a new color in understanding the Qur'an by taking into account the context of the revelation and context when the Qur'an was interpreted. This article is adapted from Abdullah Saeed's article entitled "Some Reflections on the Contextualist Approach to Ethico-legal Texts of the Quran" which he published in the Bulletin of SOAS. Therefore, this article seeks to find the vertices of Abdullah Saeed's reflection on some contextualist thinking ideas.
\end{abstract}

Keywords: Abdullah Saeed, contextual, legal ethic verses

\begin{abstract}
Abstrak
Kesadaran akan relasi antara teks, konteks dan penafsir selalu mengalami dinamika dari waktu ke waktu. Sejak masa klasik hingga kontemporer, setiap penafsir selalu berusaha menghadirkan hasil penafsiran yang memberikan maslahat bagi siapapun. Begitu juga yang dilakukan oleh para mufassir kontekstual, seperti Fazlur Rahman, Amina Wadud, Muhammad Syahrur, dan Khaled Abou El Fadl yang akan diulas secara singkat dalam artikel ini. Artikel ini adalah hasil refleksi Abdullah Saeed terhadap empat orang mufassir kontemporer dalam menafsirkan ayat-ayat ethico legal. Abdullah Saeed adalah seorang ilmuan Australia yang berasal dari Maldives. Abdullah Saeed juga hadir memberi warna
\end{abstract}


baru dalam memahami Alquran dengan memperhatikan konteks masa pewahyuan dan konteks ketika Alquran ditafsirkan. Artikel ini diadaptasikan dari tulisan Abdullah Saeed yang berjudul "Some Reflections on The Contextualist Approach to Ethico-legal Texts of the Quran" yang ia publikasikan dalam BuletinSOAS. Maka dari itu, artikel ini berusaha mencari titik simpul dari hasil refleksi Abdullah Saeed terhadap beberapa pemikiran mufassir kontekstualis.

Kata Kunci: Abdullah Saeed, kontekstual, ayat-ayat ethico legal

\section{Tipologi Paradigma Tafsir ala Abdullah Saeed}

Adanya literatur terkait penafsiran Alquran pada abad kontemporer menunjukkan adanya keinginan kuat dari sebagian kalangan Muslim, seperti para sarjana dan juga kaum awam untuk menemukan relevansi antara Alquran dan isu-isu kontemporer, tanpa harus mengurangi inti dari masing-masing di antara keduanya. Terkait dengan geliat tersebut, Abdullah Saaed ${ }^{1}$ membagi para sarjana Muslim ke dalam 3 kelompok, yaitu;

1) Tekstualis, ${ }^{2}$ yaitu; kelompok yang berargumen berdasarkan pembacaan literal terhadap Quran. ${ }^{3}$ Kelompok ini berusaha mempertahankan hasil penafsiran Alquran sebagaimana diwariskan oleh generasi terdahulu. Seakan-akan ada otoritas penafsiran yang diperoleh dari tradisi sebelumnya. ${ }^{4}$

2) Semi-tekstualis, yaitu; kelompok yang memberi sedikit kelonggaran terhadap kondisi modernitas, tetapi juga sering bersikap apologis terhadap perkembangan diskursus penafsiran modern. ${ }^{5}$ Meskipun agak sama dengan kaum tekstualis, kelompok ini masih berusaha menghadirkan sisi ethico-legal dalam bentuk modern.

Kelompok ini tidak memberikan pertanyaan fundamental terkait hubungan antara

\footnotetext{
${ }^{1}$ Abdullah Saeed adalah seorang profesor Studi Arab dan Islam di Universitas Melbourne, Australia. Beliau lahir di Maldives. Sebagaimana ditulis dalam banyak karyanya, Saeed menyebut model tafsir yang didukung dan kemudian dikembangkannya sebagai tafsir "kontekstulis". Saeed juga menyebutkan beberapa tokoh dalam bukunya "Interpreting the Qur'an", yang dianggapnya masuk ke dalam kategori kontekstualis. Dari beberapa tokoh tersebut, tampaknya Saeed lebih banyak terpengaruh pemikiran Fazur Rahman. Hal ini terlihat ketika Saeed menegaskan bahwa Fazlur Rahman adalah penggagas inti dari metode tafsir kontekstualis. Lihat Abdullah Saeed. Interpreting the Qur'an: Toward a Contemporary Approach. (London: Routledge. 2006), h. 128.

${ }^{2}$ Istilah "Tekstual” sebenarnya tidak dikenal dalam istilah penafsiran. Namun demikian, secara esensial, tafsir tekstual telah diperkenankan sejak awal munculnya tafsir. Jika meminjam istilah Fiqhiyyah, tafsir tekstual berarti memaknai Alquran secara lahiriyah, yang dalam sejarah Fiqh dipelopori oleh aliran Zahiriyah. Bagi penganut tafsir tesktual, Alquran diyakini sebagai firman Tuhan yang kebenarannya bersifat mutlak. U. Syafrudin. Paradigma Tafsir Tekstual dan Kontekstual; Usaha Memaknai Kembali Pesan Alquran. (Yogyakarta: Pustaka Pelajar. 2009), h. 38.

${ }^{3}$ Abdullah Saeed, "Some Reflections on The Contextualist Approach to Ethico-legal Texts of the Quran," dalam BuletinSOAS, 2008, hlm. 222. Lihat juga Abdullah Saeed. The Quran; An Introduction. (London dan New York: Routledge. 2008), h. 220.

${ }^{4}$ Berikut kutipannya; "The textualists seek to maintain the exegesis of the Qur'an as handed down by tradition and argue for a strict following of the text as well as the "'authorized' interpretations within the tradition". Lihat Abdullah Saeed dalam Islamic Thought; An Introduction. (New York: Routledge. 2006), h. 31-32.
}

${ }^{5}$ Abdullah Saeed, "Some Reflections on The Contextualist Approach," hlm. 221. 
sisi ethico-legal dengan konteks sosio-historis Alquran. Di antara para pendukung pendekatan ini adalah Ikhwanul Muslimin dan Jama'at-i-Islami. ${ }^{6}$

3) Kontekstualis, ${ }^{7}$ yaitu; kelompok yang meyakini bahwa kandungan Alquran bisa diaplikasikan sesuai waktu dan tempat tertentu dengan penafsiran yang berbeda. ${ }^{8}$ Kelompok ini menekankan bukan hanya konteks sosio-historis Alquran, melainkan juga akibat dari suatu produk penafsiran. Abdullah Saeed menegaskan,

"Scholars must be aware of the social, political and cultural situation of the

Quran's revelation as well as that of the place and time in which it is being interpreted". 9

Kiranya definisi singkat di atas cukup memadai untuk menjelaskan perbedaan tafsir modern dan tafsir kontekstual. Menurut Syarqawi, ada tiga kecenderungan dalam tafsir Alquran modern; 1) al-Ittijāh al-Ijtimā'i, 2) al-Ittijāh al-Adabìi, dan 3) al-Ittijāh al-'Ilmi. ${ }^{10}$ Karya tafsir yang tergolong kategori modern, -menurut J.J.G. Jansen-, bisa dilihat dalam al-Tafsir al-Maräghï, tafsir 'Izzah Darwazah -al-Tafsïr al-Hadis, tafsir Muhammad 'Abduh dan Rasyid Ridha-al-Manār, tafsir Sayyid Quthb, FïZilāl alQur'ān, dan lain-lain. ${ }^{11}$ Sedangkan tafsir kontekstual, -menurut Amin Abdullah- dapat ditandai dari dua hal, yaitu peran konteks sosio-historis dan metode penerapan makna mutable dan immutable.

Dalam artikel ini, Abdullah Saeed memaparkan bentuk-bentuk ijtihad progresif para tokoh tafsir kontekstualis terhadap ayat-ayat Ethico-legal dalam Alquran. Pentingnya mengkaji konsep ethico-legal dalam Alquran, Abdullah Saeed mengatakan,

"One of the primary concerns of this reading is that in order to understand and interpret the ethico-legal content of the Quran and relate that content to the changing needs and circumstances of Muslims today, it is important to approach the text at different levels, giving a high degree of emphasis to the sociohistorical context of the text". ${ }^{12}$

Untuk menelusuri hal tersebut, Abdullah Saeed mencontohkan beberapa ayat yang ditafsirkan oleh masing-masing tokoh, di antaranya; Fazlur Rahman, Amina Wadud, Muhammad Syahrur, dan Khaled Abou El Fadl.

${ }^{6}$ Abdullah Saeed. IslamicThought..., hlm. 32. Sebagaimana dikutip oleh Abdullah Saeed dalam "Quran: Tradition of Scholarship and Interpretation", In Encyclopedia of Religion, Farmington. MI: Thomson Gale. 2005.

${ }^{7}$ Istilah "Kontekstual" dalam dunia tafsir adalah istilah baru. Gagasan ini lahir dari keprihatinan Fazlur Rahman, -penggagas tafsir kontekstual-, tentang penampilan tafsir Alquran yang sepotongpotong (parsial). Kata kunci yang acap kali digunakan dalam tafsir kontekstual adalah "akar kesejarahan". Konteks yang dimaksud di sini adalah situasi dan kondisi yang mengelilingi pembaca. Lihat Morgan L. Walters. The Holt Intermediate Dictionary of American English. (New York: Holt, Rinehart and Winston, Inc., 1966), hlm. 169. Sebagaimana dikutip oleh U. Syafrudin. Paradigma Tafsir Tekstual dan Kontekstual, hlm. 43.

${ }^{8}$ Lihat juga Abdullah Saeed. The Quran; An Introduction, hlm. 221.

${ }^{9}$ Abdullah Saeed, "Some Reflections on The Contextualist Approach," hlm. 222.

${ }^{10}$ Dr. I. M. Syarqawi. Ittijah al-Tafsir fi Misr fi 'Asr al-Hadis, hlm. 369. Sebagaimana dikutip oleh J. J. G. Jansen. Diskursus Tafsir Alquran Modern, hlm.xxiii.

${ }^{11}$ J. J. G. Jansen. Diskursus Tafsir Alquran Modern, hlm. 20.

${ }^{12}$ Abdullah Saeed, "Some Reflections on The Contextualist Approach," hlm. 221. 


\section{Definisi Kontekstualis}

Menurut Saeed, term "kontekstualis" biasanya identik dengan para reformis Muslim. Ada istilah lain yang juga senada dengan kontekstualis, yaitu "Ijtihad Progresif ${ }^{\prime}{ }^{13}$ Istilah ini merupakan gabungan dari usaha untuk mencari makna dari ayatayat Alquran dan usaha mempertanyakan kembali makna tradisi yang sudah ada. Saeed mengatakan bahwa seseorang dikatakan kontekstualis karena beberapa kategori, yaitu; 1) Mengikuti perkembangan saat ini dengan mempertimbangkan keadilan sosial, hak asasi manusia, dan hubungan antaragama. 2) Mereka juga mempertanyakan tentang metode atau praktikapa yang sesuai dengan pemikiran tradisi Islam. 3) Mereka berargumen bahwa semua praktik dalam Islam harus disesuaikan dengan kehidupan modern dan dunia Islam saat ini. ${ }^{14}$

Kaum kontekstualis sering memfokuskan kajiannya pada upaya untuk memberikan penafsiran terhadap ayat-ayat ethico-legal dalam Alquran yang sesuai dengan kondisi dunia modern saat ini. Pendekatan ini bukan hanya sebuah respon terhadap tuntutan zaman, tetapi juga respon terhadap kaum konservatif dan pendekatan otoriter yang mendukung kaum tradisional saat ini. Maka dari itu, kontekstualis lebih dikenal sebagai gerakan kritik sosial daripada gerakan ideologis. ${ }^{15}$

Kaum kontekstual berargumen bahwa untuk memahami ethico-legal dalam ayat-ayat berkonteks politik, sosial, historis, agama, dan ekonomi adalah dengan memahami kapan ayat-ayat tersebut diwahyukan, dipahami, ditafsirkan, dan diterapkan. Dengan kata lain, -mengutip dari Fazlur Rahman- penafsiran yang mengusung ide "semangat kenabian" atau "prophetic spirit", yaitu mengungkap bagaimana Nabi seharusnya bertindak, jika beliau hidup di zaman ini. ${ }^{16}$

Lalu apa yang dimaksud dengan teks ethico-legal itu?. ${ }^{17}$ Sebelum beranjak lebih jauh, perlu diketahui bahwa Abdullah Saeed tidak menjelaskan maksud ethico-legal di dalam artikel ini secara eksplisit.

Akan tetapi, yang jelas adalah bahwa frasa Ethico-legal terdiri dari dua kata, yaitu "ethico atau ethic" yang lebih dekat jika diterjemahkan dengan "etis, beradab

${ }^{13}$ Menurut Abdullah Saeed, progresif merupakan gerak laju setelah modernis. Hal ini digambarkan seperti ini; modernists $\rightarrow$ neo-modernists $\rightarrow$ progressives. Abdullah Saeed menambahkan bahwa "progressive ijtihadis want to bring change in their communities and beyond through reinterpretation of the Islamic texts and tradition". Lihat Abdullah Saeed. Islamic Thought; An Introduction, hlm. 150. Ijtihad progresif sendiri merupakan gabuangan dari dua kata. Abdullah Saeed menjelaskan “...its combines the words ijtihad, meaning to engage in an effort to seek the meaning of a quranic verse. Progressive, meaning someone who is questioning and challenging established traditions of a particular system of thought". Lihat Abdullah Saeed, "Some Reflections on The Contextualist Approach,"hlm. 222.

${ }^{14}$ Abdullah Saeed, "Some Reflections on The Contextualist Approach,"hlm. 222. Lihat juga Abdullah Saeed. IslamicThought..., hlm. 32.

${ }^{15}$ Abdullah Saeed, "Some Reflections on The Contextualist Approach,"hlm. 223.

${ }^{16}$ Fazlur Rahman. Islam and Modernity, hlm. 6. Sebagaimana dikutip Abdullah Saeed. Islamic Thought..., hlm. 32.

${ }^{17}$ Abdullah Saeed membuat klasifikasi jenis teks dalam Alquran menurut kontennya menjadi 4 yaitu; 1) Ayat-ayat teologis, 2) Ayat-ayat Kisah, 3) Ayat-ayat Perumpamaan, dan 4) Ayat-ayat Ethicolegal. Abdullah Saeed. Interpreting the Alquran..., hlm. 1. 
atau moral" (الأخلاق). Dan kata "legal" yang diterjemahkan menjadi "hukum, aturan" (العقل الفقهىى. ${ }^{18}$ Menurut Abdullah Saeed, pada dasarnya bahasa ayat-ayat ini adalah etis bukan legal, -meskipun tidak dapat dipungkiri, bahwa ia mengandung beberapa pernyataan-pernyataan hukum penting yang dikuatkan terutama selama proses pembinaan masyarakat negara di Madinah. ${ }^{19}$

Aspek yang diinginkan Abdullah Saeed terkait dua unsur tersebut adalah bagaimana seorang mufasir dapat menggabungkan keduanya dalam menetapkan sebuah hukum. Sebut saja hukum-hukum yang berkaitan dengan gender, budaya, pluralisme agama, dan lain sebagainya. Apakah mufasir tersebut mampu menetapkan sebuah hukum yang "ramah sosial" atau justru menimbulkan perselisihan di kalangan masyarakat.

Maka dari itu, sebelum menafsirkan sebuah teks, Abdullah Saeed menghimbau kepada para mufasir untuk membedakan terlebih dahulu, mana teks yang termasuk legal, ethic, dan theological (determining whether it is legal, ethical or theological).20

\section{Gagasan Sebuah Konteks}

Secara umum, terkait dengan pemahaman terhadap Alquran, kontekstualis dapat ditandai dari 2 hal, yaitu dalam konteks yang sempit (a narrow context) dan konteks yang lebih luas (a broad context).

Jika dilihat dari kajian mereka dalam konteks yang sempit (narrow), maka kajiannya masih beredar pada kata atau kalimat yang ada di sekitar Alquran. Tahap ini dianggap penting oleh kaum kontekstualis karena mufasir harus mengetahui relasi sebuah kata (dalam ayat Alquran) dengan situasi turunnya ayat tersebut.

Selanjutnya pada tahap yang lebih luas (broad), kaum kontekstualis harus mengembangkan kajiannya pada 2 aspek, yaitu; konteks sosio-historis pewahyuan dan konteks di mana Alquran itu ditafsirkan. Terkait dengan konteks sosio-historis pewahyuan, maka pembicaraan akan mengulas tentang penerima wahyu pertama, yaitu Nabi Muhammad dan kehidupan yang melingkupinya.

Sedangkan terkait dengan konteks dimana Alquran itu ditafsirkan, maka pembicaraan akan mengarah pada konteks dimana mufasir menafsirkan sebuah ayat. Seperti waktu yang terus berubah, maka norma, nilai, dan praktik suatu zaman juga akan ikut berubah. Maka dari itu, seorang mufasir harus mempertimbangkan tahap perubahan itu. ${ }^{21}$

\footnotetext{
${ }^{18}$ Disampaikan oleh Prof. Dr. Amin Abdullah, dalam perkuliahan Hermeneutika Alquran, Kamis, 09 Januari 2014, di PPs. UIN Sunan Kalijaga, Yogyakarta.

${ }^{19}$ Fazlur Rahman. Islam. terj. Ahsin Mohammad. (Bandung: Pustaka. 2003), hlm. 43. Dikutip oleh Ghufron Hamzah, "Hermeneutika Abdullah Saeed, dalam Interpreting the Quran: Towards A Contemporary Approach," dalam buku Hemerneutika Alquran dan Hadis. (Yogyakarta: eLZAQ Press. 2010), hlm. 212.

${ }^{20}$ Abdullah Saeed, "Some Reflections on The Contextualist Approach",hlm. 227.

${ }^{21}$ Abdullah Saeed, "Some Reflections on The Contextualist Approach", hlm. 224.
} 
Salah satu contohnya dapat disimak dari penafsiran konsep surga dalam Islam. Dalam menginformasikan konsep tentang surga, Alquran menggunakan konsep yang erat kaitannya dengan kondisi budaya lokal dan imaginasi (khayalan) masyarakat setempat, yaitu kebun/taman dan musim semi, ${ }^{22}$ sungai yang mengalir, ${ }^{23}$ dan berbagai macam jenis buah-buahan. ${ }^{24}$ Perumpamaan ini merupakan pilihan yang tepat sebagai kontradiksi kondisi Arab saat itu yang hidup di gurun, panas, dan kering. Maka dari itu, perumpamaan seperti inilah yang menjadi daya tarik tersendiri dari Alquran terhadap masyarakat Arab saat itu.

Teks lainnya yang berhubungan dengan kajian yang lebih luas (the broader context) pada abad ke-VII di Hijaz adalah hal-hal terkait perempuan, dimana Alquran memberikan konsep yang diakui telah masuk pada tahap pemikiran yang progresif pada saat itu. Sebagai contoh, dapat disimak dari konsep warisan dalam Islam. Ketika lakilaki dan perempuan berada pada level (silsilah keluarga) yang sama (anak laki-laki dan anak perempuan), maka perempuan akan mendapatkan setengah bagian dari laki-laki. Pembagian model seperti ini merupakan konsep yang progresif karena; 1) perempuan Hijaz pra-Islam tidak pernah mendapatkan harta warisan, dan 2) struktur sosial saat itu memang menempatkan laki-laki sebagai orang yang memiliki tanggung jawab yang lebih besar dibanding perempuan, sehingga wajar jika perempuan hanya mendapatkan setengah.

Menurut Abdullah Saeed, contoh di atas merupakan suatu pemikiran yang progresif, karena memperhatikan konteks dimana wahyu itu turun. Maka dari itu, menurutnya, mengabaikan konteks sosio-historis turunnya ayat tersebut adalah bentuk lain dari diskriminasi terhadap perempuan. ${ }^{25}$

\section{Penafsiran Kontekstualis Terhadap Alquran}

Sepanjang sejarah Islam, penafsiran Alquran selalu didominasi dengan pendekatan legal-literalistik yang dianggap lebih aman dan lebih sesuai dalam memaknai perkataan Tuhan. Sekitar abad ke-7 hingga abad ke-12, ketika muncul ultimatum "pintu ijtihad telah tertutup", para ulama telah membatasi kreatifitas penafsiran Alquran. Baru pada abad ke-18, sarjana Muslim kontekstualis mulai menghidupkan kembali tradisi ijtihad. Salah satu tokohnya adalah Fazlur Rahman. Seperti kaum reformis yang muncul pada abad ke-18 lainnya, kelompok kontekstualis juga berupaya untuk membangkitkan kembali tradisi Islam dalam berijtihad. Banyak diantara mereka yang meninggalkan model penafsiran literalistik, terutama pada ayatayat ethico-legal.

\footnotetext{
${ }^{22}$ QS. Al-Dukhan: 52. (في جَنَّاتٍ وَعْيُوٍِن)

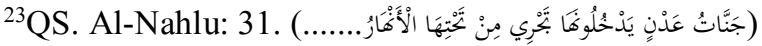

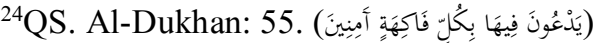

${ }^{25}$ Abdullah Saeed, "Some Reflections on the Contextualist Approach”,hlm. 225.
} 


\section{Model Penafsiran Kontekstualis}

Kelompok kontekstualis memfokuskan penafsirannya pada nilai etik dalam Alquran. Menurut Abdullah Saeed, ada empat tahapan yang menjadi aspek kunci penafsiran kelompok kontekstualis, yaitu;

Pertama, tahap ini berupa pembacaan yang masih berada pada permukaan teks.Kedua, pembacaan sudah diperluas pada tingkat analisis teks secara independen dari pengaruh historis maupun konteks. Tahap ini meliputi; 1) analisis linguistik, seperti aspek sintagmatik atau semantik dari sebuah kata atau frase. 2) konteks literal, termasuk hubungannya dengan Alquran, baik itu berkaitan dengan bagian tertentu dari Alquran atau secara keseluruhan. 3) Bentuk literal, yaitu mengamati teks (ayat) yang menunjukkan apakah teks itu sebuah perbandingan atau perumpamaan, hukum atau doa, dan beberapa relasi paralel lainnya.

Ketiga, tahap ini merupakan tahap yang sangat penting bagi kelompok kontekstualis, yaitu menganalisis makna Alquran dalam relasinya dengan penerima pertama, meliputi; 1) analisis kontekstual, termasuk faktor budaya, norma, atau nilainilai yang berlaku dalam komunitas Muslim pertama. 2) mengklasifikasi pesan dasar ayat (classifying the message's nature), seperti apakah ayat itu termasuk ayat etik atau teologi. 3) meng-eksplorasi pesan teks, apakah itu termasuk pesan universal (umum) ${ }^{26}$ atau partikular (spesifik). 4) Menghubungkan pesan tersebut ke sasaran Alquran yang lebih luas. 5) Mengevaluasi sebuah teks, dimana ia dapat diterima, dimengerti atau diaplikasikan pertama kali pada masyarakat Muslim pertama. ${ }^{27}$

Keempat, menganalisis hubungan antara makna Alquran dengan konteks saat ini, (yaitu) dimana teks tersebut akan diaplikasikan. Analisis ini juga melibatkan isuisu sosial, politik, dan ekonomi. ${ }^{28}$ Untuk lebih sederhana, dapat disarikan melalui bagan di bawah ini;

\section{(Metode Penafsiran Kontekstual Menurut Abdullah Saeed)}

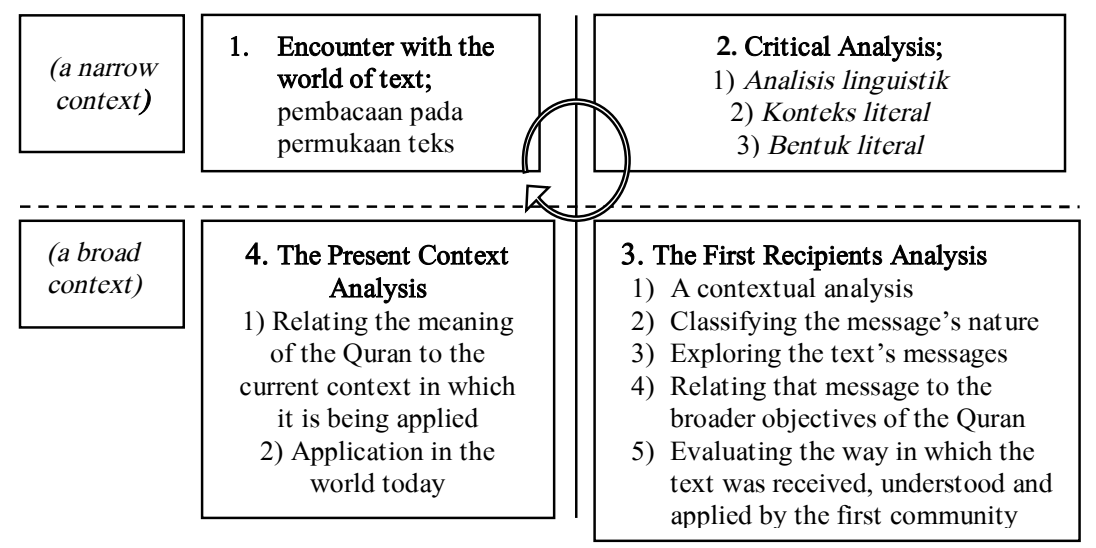

\footnotetext{
${ }^{26}$ Jaser "Audah menghubungkan makna "universal” dengan "al-Maqāsid”. Sedangkan konsep alMaqāsid menurut Jaser 'Audah adalah sejumlah tujuan (yang dianggap baik) oleh Ilahi dan konsep akhlak yang melandasi proses al-Tasyri' al-Islāmi. Jaser 'Audah. Al-MaqāsidUntuk Pemula. Terj. 'Ali Abdelmon'im. (Yogyakarta: Suka Press UIN SUKA. 2013), hlm. 5.

${ }^{27}$ Abdullah Saeed, Interpreting the Qur'an, hlm. 151.

${ }^{28}$ Abdullah Saeed, "Some Reflections on The Contextualist Approach",hlm. 227.
} 


\section{Pendekatan Baru dalam Memahami Pewahyuan}

Mayoritas Muslim percaya bahwa nabi Muhammad tidak memiliki peran aktif dalam proses turunnya wahyu, melainkan pasif, “...the Prophet Muhammad was a passive recipient of God's word (the Quran), which itself existed at a level beyond the social and cultural context of the Prophet's community". ${ }^{29}$ Artinya wahyu yang diturunkan bukanlah dari keinginan nabi Muhammad, tetapi berdasarkan kebutuhan sosial dan budaya masyarakat saat itu. Hal ini membuat mereka yakin bahwa apa yang tersurat dalam teks Alquran harus bisa diterapkan dalam kondisi kapan dan dimanapun seperti yang pernah diterapkan pada masyarakat Arab saat itu. ${ }^{30}$

Berdasarkan pemahaman ini, eksistensi Alquran berada pada alam yang tak terlihat, ("the Quran first existed in the realm of the Unseen, where it was beyond human comprehension"), yang itu diturunkan dari Allah, kemudian ke Lauh alMahfudz, malaikat Jibril, dan akhirnya kepada nabi Muhammad. Maka dari itu, menurut mereka, hanya orang-orang tertentu saja yang bisa memahami Alquran, terlebih orang yang menguasai bahasa Arab.

Dukungan Abdullah Saeed terhadap penafsiran kontekstualis sangat terlihat dalam pernyataannya,

"In contrast to traditional understandings, these alternative views emphasize the close connection between the Quran as Word of God, the Prophet and his mission, and the socio-historical context in which the Quran was revealed".

Adapun kelompok kontekstualis mengatakan, bahwa bahasa Arab adalah bahasa manusia yang menunjukkan nilai dan norma budaya tertentu. Ketika wahyu itu turun di Arab pada kondisi tertentu, maka hal itu tak lepas dari budaya Arab saat itu. Maka dari itu, Alquran bersifat dinamis. Artinya, wahyu itu tak hanya terikat dengan kondisi masa nabi, melainkan juga berkembang hingga saat ini.

\section{Ketidakpastian Makna (the Indeterminacy of Meaning)}

Sarjana tekstualis mengatakan bahwa penafsiran harus bersifat objektif. Sedangkan menurut kaum kontekstualis, penafsiran secara objektif mustahil dilakukan. Setiap penafsir pasti membawa pengalaman, nilai-nilai, keyakinan, dan persepsi masing-masing dalam memahami Alquran, yang mana akan berimplikasi pada pemaknaan teks (ayat). Maka dari itu, makna teks bersifat tidak pasti (indeterminan). Artinya, suatu makna tidak ditentukan oleh bunyi teks itu sendiri, melainkan faktor psikologi dan subjektivitas masing-masing mufasir. Maka dari itu, Abdullah menyimpulkan, "This indeterminacy is related to the idea that meanings are not concrete objects but mental entities". ${ }_{31}$

\footnotetext{
${ }^{29}$ Abdullah Saeed, "Some Reflections on The Contextualist Approach”,hlm. 227.

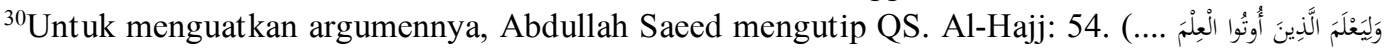

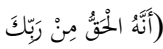

${ }^{31}$ Abdullah Saeed, "Some Reflections on The Contextualist Approach”,hlm. 228-230.
} 
Untuk menguatkan argumennya, Abdullah Saeed mengilustrasikan sebagai berikut;

"...Put simply, when an idea or meaning is conveyed to another person through language, the way in which it is received will depend on the psychological state of the receiver as well as the unique circumstance of the utterance. In the case of the "spoken word'" in particular, a word's meaning will be influenced by factors such as the tone and rhythm of the utterance, the relationship between the interlocutors and the reason for the discourse". ${ }^{32}$

Dalam proses penerimaan sebuah teks akan sangat ditentukan oleh faktor psikologi penerimanya. Menurut Abdullah Saeed, diantara beberapa faktor yang mempengaruhi aspek psikologis, seperti; 1) Nada dan irama sebuah ucapan, 2) Relasi antara interlocutor (lawan bicara) dengan sebab (reason) terjadinya sebuah percakapan (discourse).

\section{Makna Dinamis (Mutable) dan Makna Kekal (Immutable)}

Menurut sarjana Muslim tradisionalis, perdebatan mengenai makna dinamis (mutable) dan makna kekal (immutable) merupakan salah satu pokok permasalahan yang harus dibicarakan sebelum menafsirkan Alquran. Setiap mufasir harus bisa membedakan mana ayat yang tergolong mu'amalat, sehingga maknanya bisa dinamis, dan makna yang tergolong 'ibadah atau ritual yang tidak bisa diubah oleh manusia, kecuali Allah dan RasulNya. Saat ini, perdebatan seperti di atas cenderung ditinggalkan oleh kaum kontekstualis.

Beberapa contoh reinterpretasi pada periode Islam formatif, telah banyak dilakukan oleh para sahabat dan tokoh pemimpin lainnya, yang mana sebagiannya juga terekam dalam hukum Islam dan kitab hadis. ${ }^{33}$ Sebagai contoh, khalifah Umar bin alKhattab, yang dikenal sebagai salah satu khalifah yang sering mengubah sejumlah aturan hukum yang berkategori immutable (kekal, abadi) yang telah ditetapkan dalam Alquran. Sebagai contoh dapat dilihat dari kasus zakat.

Pada masa Nabi Muhammad hingga khalifah Abu Bakar, para pemuka suku mendapatkan jatah zakat. Akan tetapi, pada masa Umar bin Khathab, aturan itu diubah. Umar lebih melihatnya pada aspek politik, dimana para pemuka suku tersebut sudah tidak layak mendapatkan bantuan dana dari zakat. Terkait hal ini, Abdullah Saeed mengomentari sikap Umar dengan pernyataan, "For him, when circumstances

${ }^{32}$ Abdullah Saeed, Interpreting the Qur'an, 105. Abdullah Saeed, "Some Reflections on The Contextualist Approach",hlm. 230-231.

${ }^{33}$ Lihat Syed Sabahuddin Abdur Rahman, "Jurisprudence ala Umar - Its Contribution and Potential', Islamic and Comparative Law Quarterly, Vol. 2, No. 4, 1982, 241-9. Abdullah Saeed, "Some Reflections on The Contextualist Approach",hlm. 231. 
changed, while the underlying objective should be retained, there was no need to apply the instruction literally. ${ }^{34}$

Umar bin Khathab dapat menangkap hikmah tasyri' di balik pemberian bagian zakat kepada orang mu'allaf, bukan dari struktur teks itu sendiri, melainkan konteks umum teks. Ia memahami bahwa hikmah "penyantunan" tersebut dimaksudkan untuk memperkuat Islam yang masih lemah pada saat itu. Seiring dengan kekuasaan Islam yang membentang mulai dari jazirah Arab hingga wilayah di luar jazirah, maka tidak ada lagi "hikmah" di balik pemberian zakat kepada orang yang tidak berhak mendapatkannya. ${ }^{35}$

\section{Para Interpreter Kontekstualis}

Dalam artikel ini, Abdullah Saeed mengatakan bahwa ada 4 tokoh kunci yang tergolong ke dalam kelompok kontekstualis, yaitu; Fazlur Rahman, Amina Wadud, Muhammad Syahrur, dan Khaled Abou El Fadl. ${ }^{36}$ Dalam artikel ini, Abdullah Saeed hanya menyebutkan empat orang tokoh, sedangkan dalam karyanya yang lain, yaitu dalam buku The Quran; An Introduction, Abdullah Saeed juga memasukkan Mohammed Arkoun. Padahal menurut Abdullah Saeed -dalam bukunya tersebut-, Mohammed Arkoun adalah termasuk figur pionir dalam hermeneutik Islam kontemporer. Pemikirannya dipengaruhi oleh para intelektual post-modern seperti; Paul Ricoeur, Michel Foucault dan Jacques Derrida. ${ }^{37}$ Sedemikian pentingnya pemikiran Mohammed Arkoun, tetapi tidak dibahas Saeed dalam artikel ini. Terkait hal ini, penulis tidak menemukan alasan peringkasan tersebut.

\section{Fazlur Rahman}

Ia adalah seorang mufasir Pakisatan-Amerika yang meyakini bahwa masyarakat Muslim saat ini telah lama mengalami penderitaan "intelektual", karena banyak mengekor pada pemikiran orang-orang sebelumnya. Padahal menurutnya, ijtihad itu sangat penting dilakukan dalam rangka menciptakan masyarakat yang tak hanya selaras dengan perkembangan zaman kontemporer, tetapi juga selaras dengan prinsipprinsip ideal masyarakat Islam. Hal ini karena menurut Rahman, Alquran pada dasarnya adalah sumber prinsip etika-moral dan memang harus diarahkan pada kreatifitas pemaknaan dan hal-hal yang positif bagi keadilan manusia. ${ }^{38}$ Untuk menguatkan argumennya, Abdullah Saeed mengutip pernyataan Rahman sebagai berikut;

\footnotetext{
${ }^{34}$ Abd al-Salam al-Sulaymani, Al-Ijtihad fi al-Fiqh al-Islami. (Rabat, Morocco: Wuzarat alAwqaf, 1996), 132-3. Abdullah Saeed, "Some Reflections on The Contextualist Approach", hlm. 232.

${ }^{35}$ Nasr Hamid Abu Zaid. Mafhūm al-Nashsh. Dirāsah fĩ 'Ulum Alquran. (Beirūt: Al-Markaz alŚaqāfĩ al-'Arabì. 2000), hlm. 104.

${ }^{36}$ Lihat Abdullah Saeed. The Quran; An Introduction, hlm. 214. Dalam artikel ini, Abdullah Saeed tidak menjelaskan secara detail tentang Muhammad Arkoun sebagaimana ada dalam bukunya The Quran; An Introduction.

${ }^{37}$ Abdullah Saeed. The Quran; An Introduction, hlm. 220.

${ }^{38}$ Abdullah Saeed, Some Reflections on The Contextualist Approach..., hlm. 232.
} 
“... The implementation of the Qur'an cannot be carried out literally in the context of today because this may result in thwarting the very purposes of the Qur'an, and that, although the findings of the fuqaha' or the ulama' of Islam during the past thirteen centuries or so should be seriously studied and given due weight, it may well be found that in many cases their findings were either mistaken or sufficed for the needs of that society but not for today". 39

Berdasarkan keyakinan tersebut, Rahman memandang nabi Muhammad sebagai seorang reformis sosial yang telah memberikan perlindungan terhadap wanita, orangorang miskin, lemah, dan juga korban penindasan masyarakat saat itu. ${ }^{40}$

\section{Amina Wadud ${ }^{41}$}

Seorang tokoh sentral berkebangsaan Amerika yang mengembangkan "hermeneutika kesetaraan" ("hermeneutics of equality"). Ia menyebut gerakannya sebagai gerakan "Jihad gender" ("gender jihad"), ${ }^{42}$ yang memfokuskan kajiannya pada kesetaraan gender dan penolakan terhadap makna "jihad" yang hanya dihubungkan dengan perang dan anti-Barat. Wadud meyakini bahwa Alquran diturunkan untuk memberikan kebebasan dan menguatkan kaum perempuan. Ia mengatakan bahwa ayatayat Alquran tidak memposisikan perempuan di bawah kekuasaan laki-laki dan Alquran juga tidak menyalahkan Hawa sebagai penyebab terusirnya mereka dari Surga. ${ }^{43}$ Lebih jauh menurut Amina Wadud bahwa "the Quran places men and women on the same ontological level. ...within Islam, the only basis for differentiation between a woman and a man is their degree of "God-consciousness"' or taqwa".44

Pendekatan ini dapat dilihat dari penafsirannya terhada QS. Al-Nisa; 34,

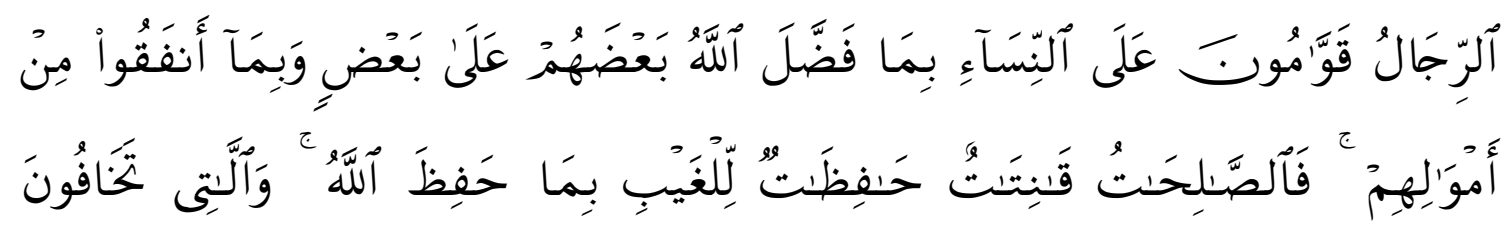

${ }^{39}$ Lihat Fazlur Rahman, “The Impact of Modernity of Islam”. Islamic Studies. Vol. 5, No. 2, Juni 1966, hlm. 127. Dikutip oleh Abdullah Saeed, "Some Reflections on The Contextualist Approach", hlm. 233.

${ }^{40}$ Abdullah Saeed, "Some Reflections on The Contextualist Approach", hlm. 233. Lihat juga Abdullah Saeed. The Quran; An Introduction, hlm. 222.

${ }^{41}$ Lihat juga Abdullah Saeed. The Quran; An Introduction, hlm. 225.

${ }^{42}$ Amina Wadud-Muhsin, Inside the Gender Jihad: Women's Reform in Islam (Oxford: Oneworld, 2006). Dikutip Abdullah Saeed, "Some Reflections on The Contextualist Approach", hlm. 233.

${ }^{43}$ Abdullah Saeed, "Some Reflections on The Contextualist Approach", hlm. 234.

${ }^{44}$ Lihat Asma Barlas, “Amina Wadud's hermeneutics of the Qur'an; Women Rereading Sacred Text', dalam Suha-Taji Farouki (ed), Modern Muslim Intellectuals and The Qur'an. (London: Oxford University Press. 2006), hlm. 114. Dikutip oleh Abdullah Saeed, "Some Reflections on The Contextualist Approach", hlm. 234. 


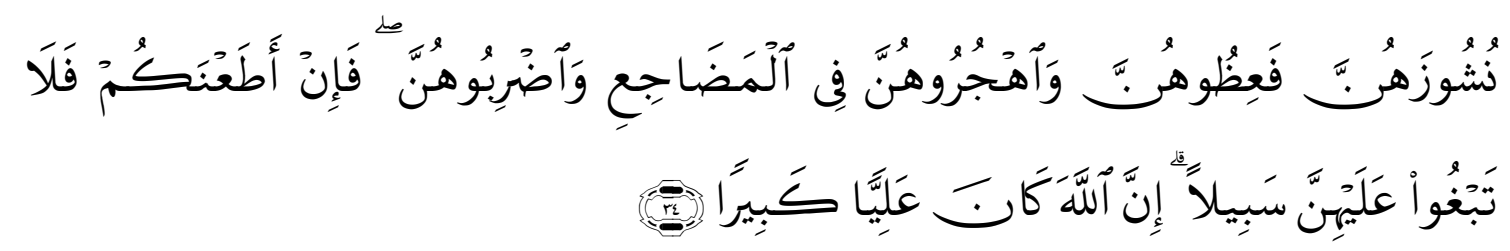

Kaum laki-laki itu adalah pemimpin bagi kaum wanita, oleh karena Allah telah melebihkan sebahagian mereka (laki-laki) atas sebahagian yang lain (wanita), dan karena mereka (laki-laki) telah menafkahkan sebagian dari harta mereka. sebab itu Maka wanita yang saleh, ialah yang taat kepada Allah lagi memelihara diri ketika suaminya tidak ada, oleh karena Allah telah memelihara (mereka). wanita-wanita yang kaти khawatirkan nusyuznya, Maka nasehatilah mereka dan pisahkanlah mereka di tempat tidur mereka, dan pukullah mereka. kemudian jika mereka mentaatimu, Maka janganlah kamu mencari-cari jalan untuk menyusahkannya. Sesungguhnya Allah Maha Tinggi lagi Maha besar.

Menurut Amina Wadud, maksud ayat ini adalah perintah bagi laki-laki untuk melindungi perempuan. Akan tetapi, kaum tradisional sering memahami ayat ini sebagai perintah untuk menguasai seluruh aspek kehidupan perempuan, khususnya terhadap kaum istri. Begitu juga halnya dengan izin memukul istri. Menurut Wadud, ayat ini tidak berbicara tentang makna "memukul" yang sebenarnya, melainkan hanya salah satu batas tindakan yang paling keras dalam menegur istri. ${ }^{45}$ Lebih lanjut, Abdullah Saeed menyimpulkan dari pernyataan Wadud,"That such an interpretation must be rejected on the basis that it contradicts basic Islamic teachings which emphasize respect and harmony between spouses and encourages mutual consultation and discussion when problems do arise" ${ }^{46}$

\section{Muhammad Syahrur ${ }^{77}$}

Dalam memahami Alquran, Syahrur memperkenalkan teori defamiliarisasi (a "defamiliarization" theory of approaching the Quran). Teori ini berusaha menghilangkan hasil penafsiran yang sudah ada dan memberikan penafsiran alternatif lainnya dalam pembacaan teks Alquran. Melalui teori ini, Syahrur berharap agar setiap pembaca merasakan Alquran itu seakan diturunkan langsung kepadanya, bukan hanya kepada nabi Muhammad atau anggap saja seakan nabi Muhammad baru saja wafat kemarin. ${ }^{48}$ Ternyata, pernyataan Syahrur ini banyak mengundang kritik di kalangan Muslim Arab.

${ }^{45}$ Pemaknaan kata "pukullah" di atas juga pernah dibahas oleh Muhammad Talbi dalam karyanya Umma al-Wasath (1996), hlm. 115. Menurut Talbi, ayat tersebut harus dipahami secara historis bukan literal. Karena menurutnya, sejarah Islam awal telah menghadirkan "gerakan feminis" yang menyertai revolusi Islam. Dikutip oleh Ronald L. Netter. "Gagasan Muhammad Talbi tentang Islam dan Politik: Konsep tentang Islam untuk Dunia Modern," dalam buku Pemikiran Islam; Dari Sayyid Ahmad Khan hingga Nasr Hamid Abu Zayd. (Jakarta: Erlangga. 2000), hlm. 133.

${ }^{46}$ Lihat Amina Wadud-Muhsin, Qur'an and Women: Rereading the Sacred Text from A Woman's Perspective. (New York and Oxford: Oxford University Press, 1999), 75-77. Dikutip Abdullah Saeed, "Some Reflections on The Contextualist Approach", hlm. 234.

${ }^{47}$ Lihat juga Abdullah Saeed. The Quran; An Introduction, hlm. 226.

${ }^{48}$ Andreas Christmann, 'The form is permanent, but the content moves': the Qur'anic Text and its Interpretation(s) in Mohammad Shahrour's al-Kitab wal Qur'an', dalam Suha Taji-Farouki, Modern Muslim Intellectuals..., hlm, 268-269. Dikutip Abdullah Saeed, "Some Reflections on The Contextualist Approach", hlm. 234. 
Pemikiran Syahrur lainnya yang mendapatkan kritik adalah ta'wil yang boleh dilakukan oleh siapa saja, baik itu orang beriman atau tidak, Muslim atau non-Muslim, atau orang Arab atau non-Arab. Pernyataannya ini didasarkan pada QS. Ali Imran; 7,

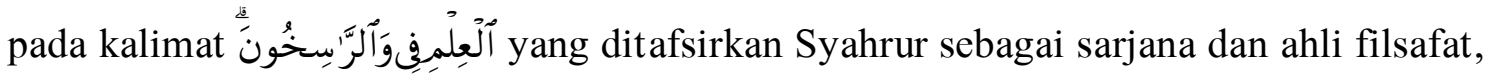
karena mereka menempati posisi yang tepat dalam masyarakat ("scholars and philosophers who occupy the most eminent place in society") dan mereka tidak harus seorang Muslim (may not necessarily be Muslim).

Sebagaimana tokoh kontekstualis lainnya, Syahrur juga mengatakan adanya kesesuaian antara Islam dan demokrasi. Hal ini didasarkan pada Q.S; 42, pada kalimat

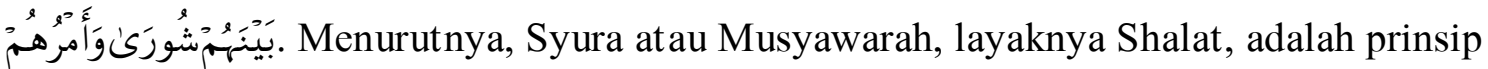
utama dalam sistem kepercayaan Islam (that shura or "consultation', like prayer, is a core principle of Muslim belief). ${ }^{49}$

\section{Khaled Abou El Fadl ${ }^{50}$}

Dalam beberapa karyanya, Abou El Fadl memfokuskan kajiannya pada konteks dimana Alquran itu ditafsirkan. Sebagai contoh, ia mengatakan bahwa sebenarnya nilai-nilai dasar dalam fiqih Islam sering tidak dimunculkan, seperti dalam rumusan ulama fundamentalis tentang Maqashid al-Syari'ah. Menurutnya, kelima aspek dalam Maqashid al-Syari'ah masih berkutat pada hasil rumusan mereka. Padahal, menurut Abou El Fadl, jika ulama masa kini mau mengembangkannya lagi dengan konteks saat ini, maka akan muncul aspek-aspek lain yang termasuk ke dalam unsur-unsur Maqashid al-Syari'ah. ${ }^{51}$

Sebagaimana tokoh kontekstualis lainnya, Abou El Fadl juga berpendapat bahwa Alquran harus terus mengalami perkembangan dan menjadi sebuah "teks terbuka" ( $a$ "work in movement", or an "open text') yang memberikan ruang penafsiran dari berbagai aspek. Di sisi lain, penafsiran Abou El Fadl juga memiliki perbedaan dengan tokoh kontekstualis lainnya. Abou El Fadl masih mempergunakan praktik hukum Muslim terdahulu yang telah berhasil membentuk masyarakat yang pluralistik dan demokratis. Ia mengatakan bahwa,

"...that traditional Islamic legal methodology, for all its limitations, was essentially "open-ended and anti-authoritarian" in nature. Fundamental to traditional Islamic law was an "evolutionary process of exploration, investigation, and adjudication" that ... resisted settlement or inertia”. However, he believes that Islamic law exists today only as a set of positive commandments (ahkam); but as "an epistemology, process, and

\footnotetext{
${ }^{49}$ Abdullah Saeed, "Some Reflections on The Contextualist Approach", hlm. 235.

${ }^{50}$ Lihat juga Abdullah Saeed. The Quran; An Introduction, hlm. 228.

${ }^{51}$ Abdullah Saeed, "Some Reflections on The Contextualist Approach", hlm. 235.
} 
methodology of understanding and searching, as a fiqh, Islamic law, for the most part, is dead', 52

Baginya, metodologi hukum Islam yang dirumuskan ulama terdahulu harus tetap dieksplorasi sebagai bentuk apresiasi terhadap khazanah pemikiran Islam.

\section{Penutup}

Sejak masa nabi Muhammad, telah banyak tradisi pemikiran dari para ulama. Maka dari itu, tradisi pemikiran tersebut harus tetap dikembangkan hingga saat ini. Kaum kontekstualis berpendapat bahwa dalam penafsiran jangan hanya berdasarkan pada teks, tetapi juga terhadap konteks masyarakat dimana teks tersebut ditafsirkan. Dengan kata lain, penafsiran teks Alquran bersifat inklusif.

${ }^{52}$ Khaled Abou El Fadl, Speaking in God's Name: Islamic Law, Authority and Women (Oxford: Oneworld, 2001), hlm. 170-171. Dikutip Abdullah Saeed, "Some Reflections on The Contextualist Approach", hlm. 236. 


\section{DAFTAR PUSTAKA}

'Audah, Jaser. Al-Maqāsid untuk Pemula. Terj. 'Ali Abdelmon'im. Yogyakarta: Suka Press UIN SUKA. 2013.

Abu Zaid, Nasr Hamid. Mafhūm al-Nash. Dirāsah fì 'Ulum Alquran. Beirūt: AlMarkaz al-Śaqāfĩ al-'Arabì. 2000.

Farouki, Suha-Taji (ed). Modern Muslim Intellectuals and The Qur'an. London: Oxford University Press. 2006.

Fazlur Rahman, “The Impact of Modernity of Islam”. Islamic Studies. Vol. 5, No. 2, Juni 1966.

Jansen, J. J. G. Diskursus Tafsir Alquran Modern.

Netter, Ronald L. Gagasan Muhammad Talbi tentang Islam dan Politik: Konsep tentang Islam untuk Dunia Modern, dalam buku Pemikiran Islam; Dari Sayyid Ahmad Khan hingga Nasr Hamid Abu Zayd. Jakarta: Erlangga. 2000.

Saeed, Abdullah. Some Reflections on The Contextualist Approach to Ethico-legal Texts of the Quran, dalam Buletin SOAS, 2008. . Islamic Thought; An Introduction. New York: Routledge. 2006. . The Quran; An Introduction. London dan New York: Routledge. 2008.

Syafrudin, U.Paradigma Tafsir Tekstual dan Kontekstual; Usaha Memaknai Kembali Pesan Alquran. Yogyakarta: Pustaka Pelajar. 2009. 